\title{
Choosing A Credit Card 1
}

Mary N. Harrison ${ }^{2}$

It is smart to shop for a credit card as carefully as you shop for any major purchase. Perhaps you have received offers in the mail asking if you would like to open a credit card account. Frequently these offers say that you are or have been "pre-approved" and urge you to respond "before the offer expires." How do you know which card offers you the best terms?

\section{Types of Credit Cards}

For many years merchants have extended the credit for the purchase of goods and services. This practice evolved into the store issued credit card. These cards are still popular and highly promoted by some retailers. A retailer or department store issued credit card is a two party credit system. The consumer buys directly from the seller of the goods and services. Generally, retailer issued cards cannot be used at other businesses.

The fastest growing segment of the credit card industry is the "multi-purpose" card. This card can be used to purchase a wide variety of goods and services from different retailers and is issued by a financial institution or investment firm. It is a three party credit system. Example: You buy an item at the store and sign a receipt. The bank pays the store for your purchase. You then pay the bank.

A third type of credit card is the charge card. This card offers credit that must be paid in full at the end of the month when the bill is received.

Choosing a credit card may seem as easy as selecting the one that offers you the most "benefits" or the most "prestige." But remember, a credit card is a form of borrowing that usually involves a "finance charge" and may include other charges such as an "annual fee."

\section{Disclosure Requirements}

In 1989 the Federal Reserve Board adopted a rule designed to make it easier for shoppers to compare the cost of competing credit cards. The rule applies to all types of cards including multi-purpose cards such as Visa, MasterCard, and Discover; department store cards such as Belks, JcPenny's, and Sears, and charge cards such as American Express, and Diners Club. The rule requires credit card issuers to use a chart which clearly discloses the terms involved in using their credit. These include the annual percentage rate (APR), method of calculating the balance, annual fees, grace period, late fees, and

1. This document is Fact Sheet FCS5038, one in a series of the Department of Family, Youth and Community Sciences, Florida Cooperative Extension Service, Institute of Food and Agricultural Sciences, University of Florida. First published: March 1991. Revised: June 2005. Please visit the EDIS Web site at http://edis ifas.ufl.edu

2. Mary N. Harrison, professor, Consumer Education, Department of Family, Youth and Community Sciences, Cooperative Extension Service, Institute of Food and Agricultural Sciences, University of Florida, Gainesville FL 32611.

The Institute of Food and Agricultural Sciences (IFAS) is an Equal Opportunity Institution authorized to provide research, educational information and other services only to individuals and institutions that function with non-discrimination with respect to race, creed, color, religion, age, disability, sex, sexual orientation, marital status, national origin, political opinions or affiliations. U.S. Department of Agriculture, Cooperative Extension Service, University of Florida, IFAS, Florida A. \& M. University Cooperative Extension Program, and Boards of County Commissioners Cooperating. Larry Arrington, Dean 
other terms associated with the credit (See Table 1 and Table 2 for examples).

Table 1.

\begin{tabular}{|c|c|}
\hline $\begin{array}{l}\text { Annual Percentage } \\
\text { Rate for Purchases }\end{array}$ & $19.8 \%$ \\
\hline Cash Advance & $23.9 \%$ \\
\hline $\begin{array}{l}\text { Grace Period for } \\
\text { Repayment of } \\
\text { Balance for } \\
\text { Purchases }\end{array}$ & 20 to 25 days \\
\hline $\begin{array}{l}\text { Method of Computing } \\
\text { the Balance for } \\
\text { Purchases }\end{array}$ & $\begin{array}{l}\text { Average Daily Balance } \\
\text { (including new } \\
\text { purchases) }\end{array}$ \\
\hline Annual Fee & $\$ 0$ \\
\hline $\begin{array}{l}\text { Minimum Finance } \\
\text { Charge }\end{array}$ & $\$ .50$ \\
\hline $\begin{array}{l}\text { Transaction Fee for } \\
\text { Cash Advances }\end{array}$ & $\begin{array}{l}\text { At a financial institution } \\
4 \% \text { of amount of } \\
\text { advance, but not less } \\
\text { than } \$ 5 \text { or more than } \\
\$ 10 \text {. }\end{array}$ \\
\hline Late Payment Fee & $\$ 30$ \\
\hline Over Limit Fee & $\$ 35$ \\
\hline
\end{tabular}

\section{Credit Card Terms}

Before selecting a credit card become familiar with the terms commonly used to describe the conditions of credit.

Annual Percentage Rate (APR): The APR is a measure of the cost of credit, expressed as a yearly rate. The term was established by the Federal Truth-In-Lending Law. A card issuer must also disclose the "periodic or daily rate," which is used to determine the amount paid for interest or finance charges. For example $18 \%$ APR is $1.5 \%$ per month or about $.0148 \%$ per day. If the APR is $12 \%$ the monthly rate is $1 \%$ and if the APR is $6 \%$ the monthly rate is $0.5 \%$ per month. Suppose one month you carried $\$ 2,000$ over on your credit card and made a
$\$ 150$ purchase on the $15^{\text {th }}$ of the month. Notice how the different APRs affect the cost of credit for that month.

$$
\begin{aligned}
& 18 \% \text { APR . . . . \$31.13 finance charge } \\
& 12 \% \text { APR ..... \$20.75 finance charge } \\
& 6 \% \text { APR ......\$10.38 finance charge }
\end{aligned}
$$

When shopping for a credit card, remember the higher the APR the higher the cost of financing. Look for a card with a low APR and low fees.

Some credit cards carry a "variable rate" APR which can go up or down. They are based on certain economic indicators such as the Prime Rate. If a credit card has a variable rate find out which index is used, what the percentage will be above the index, whether there is a minimum or maximum APR, how often and how much your rate can change and how a change will affect your minimum monthly payment.

Grace Period (Free Period): The grace period allows you to avoid paying a finance charge by paying your current balance in full before the "due date" shown on your statement. Many credit card companies offer a grace period, but not all do. If there is no grace period, a finance charge will be imposed on each purchase on the day it is posted to your account.

If your credit card offers a free grace period your bill must be mailed to you 14 days before your payment is due. This is to ensure that you have enough time to make your payment before the due date. However, 14 days does not allow much time because your bill must be mailed to you and your payment received by the company by the due date. Payment to an account is credited on the date the payment is received by the company, NOT on the date the payment was mailed.

Annual Fees: Some credit and charge card issuers charge an annual fee, a fee charged for the privilege of using the card for a year. Merchant issued credit cards generally do not charge an annual fee.

One advertising appeal is to offer a card with a complimentary first years annual fee. There will be no annual charge for the first year, but at the beginning 
of the second year the annual fee is added to the bill. People who pay their bills without carefully looking at them may pay the added fee without realizing it.

Many credit cards and some charge cards are available without an annual fee. Its smart to carefully evaluate any benefits derived from a card with a fee. Are the benefits worth the extra cost of a fee?

Late Fees: Credit cards issuers assess a late fee if a payment on the account is not received by the due date. Late fees plus additional finance charges can be a substantial penalty for a late payment. Also, many card issuers now also increase the APR on the account if a payment is made late. Late payment to one company can cause interest rates to increase on all accounts.

Credit Limits: Credit card issuers usually set a maximum amount of credit available to a card holder. If the line of credit is not sufficient, the card holder can request a higher credit ceiling. If the card holders income and credit history justify it, most companies will increase the amount of credit available up to levels established by company policy.

Since multi-purpose cards can be used at many locations some holders exceed their credit limits. To discourage this practice card issuers impose a fee for exceeding the credit limit. This fee is added each month that the account exceeds the established credit limit. Many credit cards also increase the APR charged on unpaid balances. This increases the cost of credit.

Transaction Fees: Most credit cards issued by financial institutions can be used to withdraw cash, this is called a cash advance. Fees charged for this service vary according to the card agreement and system used. In addition to extra fees paid for this service, the APR is higher and interest is charged from the time of the withdrawal. A cash advance is a cash loan.

\section{Prestige Cards}

"Gold," "Platinum," and other prestige cards are highly promoted through direct mail to people with good, established credit. This type of advertising appeals strongly to one's ego, suggesting the person is one of a select group. How are these cards different from "regular" credit cards?

- Sometimes (but not always) the APR is lower.

- The line of credit is usually higher than a regular credit card.

- Some cards have other "fringe" benefits which may, or may not, be of use to the card holder, such as travel insurance, warranties or replacement offers on items if they are lost or stolen and were purchased with the card.

Table 2.

\begin{tabular}{|c|c|}
\hline $\begin{array}{l}\text { Annual Percentage } \\
\text { Rate }\end{array}$ & $14.25 \%$ \\
\hline $\begin{array}{l}\text { Variable Rate } \\
\text { Information }\end{array}$ & $\begin{array}{l}\text { The annual } \\
\text { percentage } \\
\text { rate (APR) may vary. } \\
\text { It will be based on the } \\
\text { prime rate published } \\
\text { in The Wall Street } \\
\text { Journal plus } 8.9 \% \text {. }\end{array}$ \\
\hline $\begin{array}{l}\text { Minimum Finance } \\
\text { Charge }\end{array}$ & $\begin{array}{l}\$ 1.00 \text { whenever a } \\
\text { finance charge is } \\
\text { imposed. }\end{array}$ \\
\hline $\begin{array}{l}\text { Grace Period for } \\
\text { Purchases }\end{array}$ & $\begin{array}{l}\text { If you pay your new } \\
\text { balance in full within } \\
25 \text { days of your state- } \\
\text { ment closing date each } \\
\text { month, you will avoid } \\
\text { finance charges on } \\
\text { purchases. }\end{array}$ \\
\hline $\begin{array}{l}\text { Balance Calculation } \\
\text { Method for Purchases }\end{array}$ & $\begin{array}{l}\text { Average Daily Balance } \\
\text { (including new } \\
\text { purchases). }\end{array}$ \\
\hline $\begin{array}{l}\text { Annual Membership } \\
\text { Fee }\end{array}$ & None. \\
\hline $\begin{array}{l}\text { Cash Advance } \\
\text { Transaction Fees }\end{array}$ & $\begin{array}{l}\text { At ATMs, } 2 \% \text { of the } \\
\text { cash advance or } \$ 1 \text {, } \\
\text { whichever is greater. } \\
\text { At branches, } 2 \% \text { of the } \\
\text { cash advance or } \$ 5 \text {, } \\
\text { whichever is greater. }\end{array}$ \\
\hline Late Payment Fee & $\begin{array}{l}\$ 20 \text { if you do not make } \\
\text { a payment within } 20 \\
\text { days of the payment } \\
\text { due date. }\end{array}$ \\
\hline
\end{tabular}


Table 2.

\begin{tabular}{||l|l||}
\hline \hline $\begin{array}{l}\text { Fee for Exceeding } \\
\text { Your Credit Limit }\end{array}$ & $\begin{array}{l}\text { \$30 in each billing } \\
\text { cycle in which you } \\
\text { exceed your credit } \\
\text { limit. }\end{array}$ \\
\hline \hline
\end{tabular}

\section{Pre-Approved Credit Card Offers}

If you receive an offer of a "pre-approved credit card," it is no assurance that you will be issued the card. Card issuers can't check your credit report until you apply for credit. When you apply, the credit grantor will check your report and decide if you meet their qualifications or if you should be offered a card of another type

\section{Making Your Choice}

Most people need one or two multi-purpose credit cards. It is difficult to make a hotel reservation, reserve an airline ticket, or handle an emergency without a credit card. Select your credit card with care.

- Set the credit ceiling to fit your needs. If you are tempted to spend unnecessarily, set the credit ceiling very low so that you are not tempted to overspend. But allow for your needs, so you will not go over your credit limit.

- Comparison shop for a card. Remember, each financial institution sets its own borrower qualifications and credit card terms.

- Carefully look at all the fees that are charged and when they are assessed. Many cards advertise special rates for balance transfers. Check to see if there are transfer fees charged by your existing card company or the place to which you want to transfer the account.
- When a low APR is advertised on balance transfers, do the rates also apply to new purchases? Often they do not. Also, remember a card company applies your payment to the account with the lowest APR, leaving you to pay the higher interest, for a longer period of time, on more recent purchases.

- Look for a credit card with a grace period. Be sure the period is long enough to receive the bill and return it through the mail. Payment is credited only when it is received. Avoid cards with no grace period. Without a grace period you pay interest from the date of purchase.

- Some credit cards are two-cycle billing. Finance charges are based on purchases made during the previous 2 months instead of one month. This usually increases the cost of credit.

- Be wary of advertising that guarantees to secure a card for you. These companies usually require that you deposit a specific amount of money and then obtain a credit card secured or backed by the account. Most any financial institution will issue a secured card without the exorbitant fees that would be charged by the credit repair advertisers.

\section{Conclusion}

It is wise to have only two or three credit cards and to keep your credit balance low enough that you can comfortably make the payments.

Carefully examine your motive for getting a credit card. Keep in mind your income, financial obligations, and sales resistance. Do not obligate yourself for more than you can pay. The number of credit cards you own, the way you pay your bills, and the size of your debt, impact your credit report and credit score.

Remember credit should be your servant, not your master. 


\section{References}

Bankcard Holders of America, All That Glitters

is Not Gold, Washington D.C., 2002.

Credit Research Center, Credit Card Billing

Practices, Purdue University, West Lafayette,

Indiana, 2001.

Federal Trade Commission, Choosing and Using Credit Cards, Washington D.C., 12/98.

National Consumer Law Center, Surviving Debt, Boston, Massachusetts, 1999. 